component of the political process and that the feudal mode of production was built into the very essence of Malay society.

In chapter two, Hua explores how the growth of British penetration (beginning with the influence of Francis Light in 1786) laid the foundations for communalism in multiracial Malaysia. The evidence presented is elaborate but also overlapping at times. The primary argument begins with the insight that to preserve their presence, the British adopted the "divide and rule" strategy. The introduction of capitalism and a division of labor along racial lines prevented any form of unity among the peasants and also led to the grooming of a bourgeois class including Malays, Chinese and Indians. Hua sees this as a necessary strategy if the extraction of surplus from the peninsula was to continue. Most importantly, the British masqueraded their political and administrative control through the use of Malay puppet rulers.

Chapters three through five assess the events leading to anti-colonial movements and the transfer of power to the local ruling class. Hua illustrates the major institutional changes that followed the struggle for independence and offers an impressive list of evidence to support his description of the current class structure in Malaysia. While discussing the dependent nature of Malaysian society in relation to the metropolis, he points out that "the local ruling class continues to be dominated, because the pursuit of their own interests is circumscribed by the imperialist interest they serve. And while the neo-colonial situation exists, it is the workers and peasants who are exploited by the local and metropolitan ruling class" (111).

The division of the masses through communalism has prolonged the deprivation of democratic rights. The last part of the book focuses on this issue. Hua asserts that the New Economic Policy that was first promulgated in 1970, is another indication of the "institutionalization of communalism by the Malaysian state." Other indicators are the imposition of the Amended Internal Security Act authorizing arrests and detention without trial; the Printing Press Ordinance of 1971; and anti-labor legislation.

Class and Communalism in Malaysia is an excellent analysis of the socioeconomic situation in that country. It sheds much needed light on the complex relationship between the domestic class structure and neocolonialism. On a much broader scale, in raises fundamental concerns about the nature of the international economic order.

Kansas State University

Sumil Kukreja
Helmut R. Wagner, Alfred Schutz: An Intellectual Biography, Chicago: University of Chicago Press, 1983. 357 Pp. $\$ 15.95$ (paper).

Wagner's contribution to the Heritage Sociology series, edited by Morris Janowitz, was published in paperback this year (1986). The book is a shortened version of the original "personal and intellectual biography" composed between 1974 and 1979, of which "about 20 percent" remains (xi). Even so, it is quite comprehensive, first tracing Schutz's life in broad overview, then focusing on details of the personal and intellectual relationships that he had with other scholars, and finally exploring the relationship of his work to that of Leibniz, Bergson, and especially Husserl. This comprehensiveness is the strength of the book. Nothing comparable has been provided anywhere else. I doubt, however, that any but the most committed social theorists and Schutzians have an interest in exploring the details. The most interesting parts of the book, the first on Schutz's life and the last on his uses of Leibniz, Bergson, and Husserl, will be of interest to those who only want a general knowledge of Schutz's work. The middle section, dealing with many predecessors, contemporaries, and successors of Schutz, drags. Its usefulness as an introduction to the American phenomenological dialogue has to be balanced against the repetition of its seemingly endless listing of names. Yet, on the whole, Schutz's criticism of objectivist sociology shines through the text.

The first part - "A Life of Intellectual Devotion" - explores Schutz's life course, dividing it into fourteen different stages. Wagner is not the first to note that Schutz's intellectual "life-plan" was designed and fulfilled with a very high degree of consistency. The "one single, ultimate, theoreticalphilosophical purpose" informing his intellectual life was "the creation of a radically subjective sociology of understanding" (pp. 16, 115). This was so from his first synthesis of Husserl, Bergson, and Weber in Der sinnhafte Aufbau der Sozialen Welt (1932, translated in an English edition as The Phenomenology of the Social World, 1967), until his dying efforts to produce the outline of his philosophy that has been gathered into The Structure of the Life-World (Schutz and Luckmann, 1973).

The young Schutz attempted a clarification of Weber's methodological tenets for an "interpretive" sociology through the phenomenologies of Bergson and Husserl. His later intellectual projects were primarily concerned with using the insights of diverse philosophers and sociologists to extend and modify the original presentation of his ideas. In his busy and sometimes tumultuous life, Schutz started major projects (after completing Der 

sinnhafte Aufbau) but was only able to complete his many papers, journal
articles, and lectures.

According to Wagner, Schutz compartmentalized his life into fou distinct "spheres of relevances:" one of family and friendship concerns, another oriented to business (international banking), a third concerned the pursuit of scholarly theoretical/philosophical goals, and the fourth revolved around his love for music (17). Though (or because) divided, the different spheres intruded upon each other as demands for his time and energy.

Wagner also suggests that Schutz's life as a young man laid an experiential foundation for his theoretical distinctions (10). After fulfilling his military duties in World War I, Schutz experienced the estrangement in Austrian society of "compulsory roles" in the public world from the "life of meaning" characterizing family and cultural pursuits. For Wagner, this experience was a "bridge" to the neo-Weberian emphasis on scientific detachment. The "compulsory" world required an impersonal explanation. On the other hand, Schutz's longing for personal closeness in friendship and family relations was probably a "bridge" to his theoretical concern for intersubjectivity. Certainly, his description of the we-relationship has little to do with compulsory action. I cannot judge the validity of Wagner's assertions, but he has isolated the fundamental tension in Schutz's work - that between the emphasis on subjective dynamism in social life and the definition of science as a rational, impersonal "objective context of knowledge."

Like a host of his intellectual peers, Schutz emigrated from Europe (liv ing for a while in Paris) to America during the rise of Nazism in Germany. This unhappy circumstance was the context in which Schutz in Germany. knowledge of and acquaintanceship with many of Europe's and America's most important intellectuals (he already knew. Husserl). The second part of the book - "An Ongoing Community of Scholars" - discusses in more detail some of the major currents of thought that influenced his work and specific intellectuals he mentioned in his work and/or knew personally. Philosophers and sociologist, ranging from Simmel to Merleau-Ponty to Parsons, are discussed in relation to Schutz. Voegelin, a phenomenologist of history, and Gurwitch, a phenomenological psychologist, merit a chapter each. In perhaps the most interesting section, the influence of American pragmatists and early sociologists is noted.

Part two indicates the breadth, but not depth, of Schutz's thought. It seemed to me to take a long time to read, probably due to the lack of a central argument to tie all the threads together. It does, however, familiarize the reader with the philosophical discourse that Schutz had entered.
Part three - "Before and Beyond the Sociology of the Life-World" dealing with Leibniz, Bergson, and Husserl, is the most interesting part of the book. It first indicates Schutz's indebtedness to Leibniz's monadology and to Bergson's phenomenology of inner time consciousness for many of his core concepts. While never accepting either philosophy as a whole, it is demonstrated that he borrowed extensively from them in defining his own project.

Next, Wagner points out that Schutz borrowed most extensively from Husserl, and this was a source of many doubts and apprehensions, especially toward the end of his life. Schutz's core concepts - "natural attitude," "intersubjectivity," and "typification" - were lifted from Husserl. However, two types of criticisms served to undermine Schutz's faith in Husserl's delineation of these concepts (307-324). To begin with, Schutz never had much faith in Husserl's transcendental solution to the problem of intersubjectivity. He finally, in 1957, expanded these doubts into an extensive criticism of Husserl's solutions to the problems. For Schutz, taking the standpoint of the Transcendental Ego to demonstrate the nature of intersubjectivity involved the attempt to pluralize a term that could only be singular, and therefore failed.

The other problem with Husserl's phenomenology dealt with its clarity as a philosophy. At the same 1957 conference where Schutz presented his criticisms of transcendental phenomenology, Fink criticized Husserl's philosophy for never passing from an "operational" to a "thematic" stage. Operational concepts are not clarified, but are used in an initial stage of clarifying concepts that will be used as tools in the thematic stage of building a philosophy. Schutz even doubted that the concept of typicality had ever passed the operational stage (323).

Wagner concludes by describing Schutz as a " "critical phenomenologist" (327) who wanted to build a systematic phenomenological base guiding theory building in the social sciences. In doing so Schutz could not overlook the problems internal to phenomenology itself. And, his brand of sociology remains internal to phenomenology. Wagner's accurate depiction of Schutz also points to his limitation: the singular concern with "radical subjectivity." I think that sociologists have to question whether this concern is adequate to resolve contemporary sociological problems. Can it, for instance, be the basis for an adequate historical sociology? Can we grasp contemporary relations of power, authority, and stratification from this perspective?

Schutz mastered phenomenological philosophy and demonstrated its relevance for a neo-Weberian, interpretive sociology. As Wagner points out, 
his work is a "mandate" (329) calling for critical philosophical and phenomenological inspection of problems of social science methodology. Even if Schutz's own conclusions about methodology do not adequately address the full spectrum of sociological problems, the critical philosophical stance characterizing his intellectual life is an excellent mandate for sociology.

University of Kansas

Christopher Bohling

\section{BOOKS FOR REVIEW}

This list represents all the books that MARS has for review. Anyone interested in reviewing one of these, or in submitting a review of another book for consideration, should write:

\author{
Travis Patton \\ Book Review Editor \\ Mid-American Review of Sociology \\ Dept. of Sociology \\ University of Kansas \\ Lawrence, KS 66045
}

Abels, Paul and Michael J. Murphy

1981. Administration in the Human Services: A Normative Systems Approach. Englewood Cliffs, New Jersey: Prentice-Hall, Inc.

Bagby, Wesley M.

1981. Contemporary American Social Problems. Chicago: Nelson-Hall, Inc., Publishers.

Berkowitz, William R.

1982. Community Impact: Creating Grassroots Change in Hard Times. Cambridge, Maryland: Schenkman Publishing Company, Inc.

Brody, Ralph.

1982. Problem Solving: Concepts and Methods for Community Organizations. New York: Human Sciences Press, Inc.

Dillard, John M.

1933. Multicuitural Counseling: Toward Ethnic and Cultural Relevance in Human Encounters. Chicago: Nelson-Hall, Inc.

Dougherty, Flavian, (ed.).

1982. The Meaning of Human Suffering. New York: Human Sciences Press. Epstein, Gerald, M.D.

1981. Waking Dream Therapy: Dream Process as Imagination. New York: Human Sciences Press.

Fardan, Dorothy Blake.

1981. Understanding Self and Society: An Islamic Perspective. New York: Philosophical Library, Inc.

Fields, Rona M.

1985. The Future of Women. New York: General Hall, Inc. 